\title{
Cardiovascular Risk of Community-Dwelling Elderly from a City in Northeastern Brazil: Correlations with Vitamin D and Parathormone
}

\author{
Lídia Ribeiro de Carvalho', Cecília Maria R. G. de Carvalho', Sandra M. L. Ribeiro²*, \\ Ivone F. de Oliveira C. Nunes ${ }^{1}$, Raquel Galvão Figueredo ${ }^{1}$, Amanda Marreiro Barbosa ${ }^{1}$, \\ Francisco Erasmo de Oliveira ${ }^{3}$, Dilina do Nascimento Marreiro ${ }^{1}$, \\ Marcos David Figueiredo de Carvalho' ${ }^{1}$, José Machado Moita Neto ${ }^{1}$ \\ ${ }^{1}$ Federal University of Piaui (UFPI), Teresina, Brazil \\ ${ }^{2}$ School of Arts, Sciences and Humanities, University of São Paulo, São Paulo, Brazil \\ ${ }^{3}$ Laboratório Med Imagem, Teresina, Brazil \\ Email: ${ }^{*}$ smlribeiro@usp.br
}

Received 6 April 2014; revised 7 May 2014; accepted 16 May 2014

Copyright (C) 2014 by authors and Scientific Research Publishing Inc.

This work is licensed under the Creative Commons Attribution International License (CC BY).

http://creativecommons.org/licenses/by/4.0/

c) (i) Open Access

\section{Abstract}

We investigated the cardiovascular disease (CVD) risk of the elderly in a city in northeastern Brazil, and the correlation of this risk with vitamin D and PTH status. We studied 359 elderly, both genders, from Piaú-Teresina-Brazil. Variables investigated: body mass index, waist circumference, systolic and diastolic blood pressure. A subsample $(n=100)$ was investigated for biochemical analyses: PTH and 25(OH)-vitamin D levels; total, HDL and LDL-cholesterol; and fasting glucose. High blood pressure, abdominal obesity, sedentarism, high total cholesterol, high triacylglycerol levels, as well as low vitamin $D$ levels, were, among the investigated variables, the most prevalent. Visceral adiposity and low vitamin $D$ were found to be more prevalent in women than in men, whilst alcohol intake and smoking were more prevalent in men. The correlation between vitamin D, PTH and the investigated risk variables, under our study conditions, were not significant.

\section{Keywords}

Cardiovascular Diseases, Risk Factors, Elderly, Vitamin D, PTH

\footnotetext{
"Corresponding author.
}

How to cite this paper: de Carvalho, L.R., et al. (2014) Cardiovascular Risk of Community-Dwelling Elderly from a City in Northeastern Brazil: Correlations with Vitamin D and Parathormone. Food and Nutrition Sciences, 5, 1056-1064. 


\section{Introduction}

Aging processes enhance the risk to chronic diseases, such as obesity, hypertension, type II diabetes mellitus, dyslipidemias, and cardiovascular diseases. In this way, we can find a number of published articles investigating risk factors and different strategies to manage the associated diseases [1]-[3].

Recent researches have shown an important role of vitamin D in the development of many chronic diseases. This vitamin binds to its receptors (vitamin D receptors-VDR), constituting a complex capable of modifying pathways of gene expression, or other non-genomic pathways, in a number of tissues [4]-[6]. Several systems, directly or indirectly related to cardiovascular function seem to be influenced by the binding of vitamin $\mathrm{D}$ to its receptors. For instance, we can count effects on the renin-angiotensin-aldosterone system; effects on vascular endothelial growth factor and cytokine production; effects on endothelial cell function and myocyte calcium influx [7]-[14]. In addition, low vitamin D levels are associated with high parathormone (PTH) levels, which in turn are associated with left ventricular hypertrophy and heart failure [15].

With regard to nutritional deficiencies that are typical of aging, many studies have shown low levels of vitamin D in elderly people. Classic studies have suggested the prevalence of vitamin D deficiency in these individuals to be close to $40 \%$ [16]-[18]. Brazilian studies have shown a prevalence varying from $5 \%$ to $25 \%$ [17]. Taking into account the institutionalized elderly, this prevalence can reach 71.2\% [11]. Therefore, the aging process can result in a combination of some risk factors for CVD.

Despite the importance of investigating vitamin D and associated diseases, there are still few regional studies in Brazil, particularly in some cities of northeastern of the country. As such, the aim of this study was to investigate the CVD risk in elderly from Teresina-PI-Brazil, and the correlation of this risk with vitamin D and PTH status. Considering the fast population aging [19], this kind of study may contribute to the management of the high cost of diseases associated with this population's group.

\section{Material and Methods}

\subsection{Subjects}

This is an observational, descriptive, and cross-sectional study. The participants were elderly (above 60-years old), of both genders, and were community-dwelling in Teresina, Piauí-Brazil. Subjects were selected using data from a Brazilian Ministry Health Program (Health Family Strategy). The sample size was calculated from the standard deviation estimative of $28.5 \mathrm{ng} / \mathrm{mL}$ of $25(\mathrm{OH})-\mathrm{D}$ [11], with a confidence level of $95 \%$ and sample error of $5.6 \mathrm{ng} / \mathrm{mL}$. We excluded subjects that were bedridden, those that used a wheelchair, those with hearing or talking impairments, those who were taking vitamin D or calcium supplements and those with diseases related to vitamin D metabolism (for instance, kidney or liver diseases). The guidelines for human studies were followed according to the Declaration of Helsinki. The volunteers elected to the study signed their informed consent, and the project was approved by the Ethics Committee of the Federal University of Piauí, protocol number 0386.0.045.000-10.

\subsection{Assessments}

Data were obtained during a house interview, adopting a questionnaire that had been pre-tested in a previous pilot experiment. Data were collected from February to June, 2011. The anthropometric measurements were: body weight (Plenna scale, $150 \mathrm{Kg}$ ), knee height-measured with a caliper consisting of an adjustable measuring stick with a blade attached to each end, at a $90^{\circ}$ angle [20] [21] —and waist circumference (WC), measured with an inelastic fiberglass tape. From the measurements, we estimated the height [20], and calculated the body mass index $\left[\mathrm{BMI}=\right.$ weight $\left./(\text { height })^{2}\right]$. To classify the nutritional status according to BMI, we adopted the recommendation of the Pan-American Health Organization; normality when BMI was between $23-28 \mathrm{~kg} / \mathrm{m}^{2}$, overweight when $28 \mathrm{~kg} / \mathrm{m}^{2} \leq \mathrm{BMI}<30 \mathrm{~kg} / \mathrm{m}^{2}$ and obesity when BMI $\geq 30 \mathrm{Kg} / \mathrm{m}^{2}$ [22]. To identify cardiovascular risk from the waist circumference, we adopted standards proposed by the WHO [23], where waist circumference $\geq 102 \mathrm{~cm}$ for men and $\geq 88 \mathrm{~cm}$ for women constituted cardiovascular risk.

Blood pressure was measured following the VI Brazilian Guidelines for Hypertension (BD sphygmomanometer). According to these guidelines, hypertension was defined as systolic blood pressure (SBP) $\geq 140 \mathrm{~mm} / \mathrm{hg}$ and/or diastolic blood pressure (DBP) $\geq 90 \mathrm{~mm} / \mathrm{Hg}$. The values were obtained by calculating the average of two measurements [24]. For participants with diabetes, hypertension was defined when SBP was $\geq 130$ and/or DBP 
$80 \geq \mathrm{mmHg}$. In addition, participants who referred to taking medicines for hypertension were also considered as having high blood pressure [25].

\subsection{Biochemistry}

For blood sample collection, the participants were required to attend the Health Unit on a scheduled day, during the morning, after fasting and rest of between $8-12$ hours. In case of any difficulty, the researcher went to the participant's house to carry out blood withdrawal. The blood was centrifuged and the plasma was frozen until analysis. Biochemical analyses were performed at the Hospital Med Imagem, Teresina, Piauí, Brazil. PTH and 25(OH)-D levels were analyzed by chemiluminescence method (IMMULITE 200 and Diasorin LIAISON ${ }^{\mathrm{TM}}$, USA, respectively). The reference range for PTH was 12 to $72 \mathrm{pg} / \mathrm{mL}$, and the classification of vitamin D levels followed that proposed by Holick et al. [26]: $\leq 20 \mathrm{ng} / \mathrm{mL}$-vitamin D deficiency; 21 to $29.9 \mathrm{ng} / \mathrm{mL}$-insufficient level; $\geq 30 \mathrm{ng} / \mathrm{mL}$ to $100 \mathrm{ng} / \mathrm{mL}$-adequate levels. Plasma lipids were analyzed by automation (ViteK Systems Clinline 150-Biomerieux). HDL-cholesterol and triacylglycerol were measured by enzymatic colorimetry, and LDL-cholesterol was calculated according to the Friedwald equation [27]. We adopted reference values according to the IV Brazilian Guidelines on dyslipidemia and arterosclerosis prevention [28]. Fasting blood glucose was measured by enzymatic colorimetric method, and the reference values followed those of the Brazilian Society of Diabetes [29]. Participants with blood glucose values $\geq 126 \mathrm{mg} / \mathrm{dL}$ and those with normal values, but under pharmacological treatment, were considered as diabetic.

\subsection{Data Analysis and Statistical Methods}

Numeric data were presented as mean and standard deviation. The categorical variables were presented as percentages. The Kolmogorov-Smirnov test revealed that none of the investigated variables presented normal distribution. Therefore, we adopted non-parametric tests (Mann-Whitney test and Kruskal-Wallis test). The association between categorical variables was investigated by the Chi-square test $\left(\chi^{2}\right)$, and cases where more than $25 \%$ of the cells presented $\mathrm{n}<5$ we adopted the Fisher exact-test. Some data were correlated by Spearman test. We considered a p-value $<0.05$ as significant for all analyses and the analyses were performed with the Statistical Package for Social Sciences (SPSS ${ }^{\circledR}$ ), version 18.0.

\section{Results}

\subsection{Sociodemographic and Clinical Aspects}

Table 1 depicts the variables investigated and Table 2 presents the prevalence of cardiovascular risk, for both genders. With regard to demographic data, the majority of the participants declared living with a partner; most of them reported low schooling and low income.

Both men and women presented a low prevalence of total obesity, as evaluated by BMI values. However, abdominal obesity, evaluated by WC, suggested that the majority of women presented CVD risk, but not the majority of men. Both genders presented an elevated prevalence of high blood pressure.

Biochemical analysis suggested low levels of 25(OH)-D for both genders, but women presented lower values than men. PTH values were between normality ranges for the majority of both men and women. High fasting glucose was relatively low in prevalence both in men and women, although the mean values were higher in men. The prevalence of high total cholesterol and triacylglycerol was elevated in both genders, without any difference between genders. In turn, the prevalence of both high LDL-cholesterol and low HDL-cholesterol was lower than other markers of blood lipids, although women showed a higher prevalence than men. Alcohol intake and smoking were referred by a small percentage of the participants; men reported these habits more than women. In addition, a sedentary lifestyle was referred by the majority of participants, of both genders.

In order to turn our study broader, we investigated cardiovascular risk by taking into account other independent variables. With regard to schooling, total obesity was higher in the subjects with higher schooling level. In contrast, a sedentary lifestyle was more common in subjects with lower schooling (illiterate $=7.2 \%$ and $81.3 \%$ for total obesity and sedentary lifestyle, respectively; fundamental level $=12.4 \%$ and $73.3 \%$ respectively; intermediate level and above: $16.9 \%$ and $55.9 \%$ respectively; $\mathrm{p}<0.05$ for all the comparisons). Biochemical variables and blood pressure values did not present any significant association with regard to schooling. Considering marital status, high blood pressure, abdominal obesity and low HDL-cholesterol were more prevalent in the 
Table 1. Distribution of the variables investigated, according to gender*

\begin{tabular}{|c|c|c|c|c|}
\hline Demographic variables & $\begin{array}{c}\text { Male }(\mathrm{n}=138) \\
\mathrm{N}(\%)\end{array}$ & $\begin{array}{c}\text { Female }(\mathrm{n}=221) \\
\mathrm{N}(\%)\end{array}$ & & $\begin{array}{c}\text { Total }(\mathrm{n}=359) \\
\text { N (\%) }\end{array}$ \\
\hline \multicolumn{5}{|l|}{ Age group } \\
\hline $60-69 y$ & $66(47.8)$ & 117 (52.9) & $\chi^{2}=0.98$ & $183(51.0)$ \\
\hline $70-79 y$ & 49 (35.5) & $73(33.0)$ & $\mathrm{p}=0.61$ & $122(34.0)$ \\
\hline$\geq 80 \mathrm{y}$ & $23(16.7)$ & $31(14.0)$ & & $54(15.0)$ \\
\hline \multicolumn{5}{|l|}{ Marital status } \\
\hline Without partner & $20(14.5)$ & $114(51.6)$ & $\chi^{2}=49.96$ & $134(37.3)$ \\
\hline With partner & $118(85.5)$ & $107(48.4)$ & $\mathrm{p}<0.001$ & $225(62.7)$ \\
\hline \multicolumn{5}{|l|}{ Schooling } \\
\hline Illiterate & $52(37.7)$ & 87 (39.4) & & $139(38.7)$ \\
\hline Fundamental level ${ }^{1}$ & $65(47.1)$ & $96(43.3)$ & $\chi^{2}=0.52 \mathrm{p}=0.77$ & $161(44.8)$ \\
\hline Intermediate level or above ${ }^{1}$ & $21(15.2)$ & $38(17.2)$ & & $59(16.4)$ \\
\hline \multicolumn{5}{|l|}{ Family Income } \\
\hline$<2 \mathrm{MS}^{2}$ & $71(51.4)$ & $142(64.2)$ & $\chi^{2}=10.42$ & $213(59.3)$ \\
\hline $2-5 \mathrm{MS}$ & 44 (31.9) & $64(29.0)$ & $p=0.005$ & $108(30.1)$ \\
\hline$>5 \mathrm{MS}$ & $23(16.7)$ & $15(6.8)$ & & $38(10.6)$ \\
\hline $\begin{array}{c}\text { Anthopometric and } \\
\text { BP variables }\end{array}$ & $\begin{array}{c}\text { Male }(\mathrm{n}=138) \\
\text { Mean (SD) }\end{array}$ & $\begin{array}{c}\text { Female }(\mathrm{n}=221) \\
\text { Mean }(\mathrm{SD})\end{array}$ & p-value ${ }^{*}$ & $\begin{array}{c}\text { Total }(\mathrm{n}=359) \\
\text { Mean }(\mathrm{SD})\end{array}$ \\
\hline $\operatorname{BMI}^{3}\left(\mathrm{~kg} / \mathrm{m}^{2}\right)$ & $24.6(3.8)$ & $25.2(4.4)$ & 0.065 & $25.0(4.2)$ \\
\hline WC $(\mathrm{cm})$ & $96.8(10.3)$ & $98.2(12.5)$ & 0.072 & 97.7 (11.7) \\
\hline $\mathrm{SBP}^{4}(\mathrm{mmHg})$ & $131.7(19.0)$ & $131.6(22.2)$ & 0.679 & $131.6(21.0)$ \\
\hline $\mathrm{DBP}^{5}(\mathrm{mmHg})$ & $78.3(11.0)$ & 77.6 (11.7) & 0.391 & 77.9 (11.5) \\
\hline Biochemical Variables & $\begin{array}{l}\text { Male }(\mathrm{n}=42) \\
\text { Mean (SD) }\end{array}$ & $\begin{array}{l}\text { Female }(\mathrm{n}=38) \\
\text { Mean (SD) }\end{array}$ & p-value ${ }^{*}$ & $\begin{array}{c}\text { Total }(\mathrm{n}=100) \\
\text { Mean }(\mathrm{SD})\end{array}$ \\
\hline 25(OH)-D (ng/mL) & $25.7(9.2)$ & $20.2(6.2)$ & 0.001 & $22.5(8.0)$ \\
\hline PTH (pg/mL) & $42.0(22.5)$ & 39.3 (19.7) & 0.555 & 40.7 (20.9) \\
\hline Fasting Glucose (mg/dL) & $108.0(23.6)$ & $98.4(22.7)$ & 0.024 & $102.4(23.4)$ \\
\hline Total Cholesterol (mg/dL) & $239.2(36.8)$ & $251.8(55.8)$ & 0.346 & 246.5 (48.9) \\
\hline LDL-Cholesterol (mg/dL) & $145.0(25.7)$ & $158.6(50.9)$ & 0.335 & $152.9(75.6)$ \\
\hline HDL-Cholesterol (mg/dL) & $51.6(9.4)$ & $51.1(6.9)$ & 0.922 & $51.3(8.0)$ \\
\hline Triacylglycerol (mg/dL) & $231.1(95.9)$ & $210.3(57.4)$ & 0.444 & $211.5(75.6)$ \\
\hline
\end{tabular}

${ }^{*}$ Category variables were compared by Chi-squared test $\left(\chi^{2}\right)$, and numeric variables were compared by Mann-Whitney Test. ${ }^{1}$ Complete or incomplete; ${ }^{2} \mathrm{MS}=$ Minimal salary; ${ }^{3} \mathrm{BMI}=$ body mass index; ${ }^{4} \mathrm{SBP}=$ systolic blood pressure; ${ }^{5} \mathrm{DBP}=$ diastolic blood pressure. 
Table 2. Prevalence of cardiovascular risk, according to the investigated parameters.

\begin{tabular}{ccccc}
\hline Anthropometric and BP parameters & Total $\mathrm{n}=359$ & Male $\mathrm{n}=138$ & Female $\mathrm{n}=221$ & $\mathrm{p}$ \\
\cline { 2 - 4 } High blood pressure & $\%$ & $\%$ & $\%$ & 0.124 \\
Total obesity & 71.3 & 66.7 & 74.2 & 0.688 \\
Abdominal obesity & 11.1 & 9.4 & 12.2 & $<0.001$ \\
Alcohol intake & 65.2 & 30.4 & 86.9 & $<0.001$ \\
Smoking & 22.6 & 34.8 & 14.9 & 0.001 \\
Sedentary & 11.7 & 15.2 & 9.5 & $\mathrm{p}$ \\
\hline Biochemical parameters & 73.5 & 74.6 & $\mathrm{n}=58$ & 0.709 \\
\hline Low vitamin D & $\mathrm{n}=100$ & $\mathrm{n}=42$ & $\%$ & 0.001 \\
Low PTH & $\%$ & $\%$ & 93.1 & 0.355 \\
High fasting glucose & 82.0 & 66.7 & 3.4 & 0.177
\end{tabular}

participants living without a partner (with partner $=65.3 \%$, 56.9\% and 23.2\%, respectively; p $<0.05$ for all comparisons; without partner $=81.3 \%, 79.1 \%$ and $45.2 \%$, respectively). In turn, alcohol intake was higher in participants living with a partner $(27.1 \%$, versus $14.9 \%$; $\mathrm{p}<0.05)$. There were no differences in any of the risk factors when stratified for income. When grouping the participants according to age intervals (60 - 69, 70 - 79 and above 80 years), the only variable that was significantly different in the groups was alcohol intake (29.5\%, $15.6 \%$ and $14.8 \%$ respectively, $\mathrm{p}<0.05)$.

\subsection{Correlation between Vitamin D and Parathormone with Cardiovascular Risk}

Table 3 shows the correlation between vitamin D and variables related to cardiovascular risk, and Table 4 shows the correlation between PTH and the same variables. We did not observe any significant correlation of vitamin D levels and any of the variables. With regard to PTH, only DBP presented significant correlation with this factor.

\section{Discussion}

We investigated some variables related to CVD risk of elderly individuals in a city in the northeastern Brazil, and the correlation between those variables and vitamin D and PTH status. We observed that the most prevalent risk factors were: high blood pressure, abdominal obesity, sedentarism, high total cholesterol, high triacylglycerol, and low vitamin D. We also found that abdominal adiposity and low vitamin D were variables that were more prevalent in women than in men, whilst alcohol intake and smoking were more prevalent in men. However, we did not find significant correlation between vitamin D, PTH and any risk variables investigated.

The correlation investigated in the present study show divergences in literature. With regard to adiposity, Kimmons et al. [30], in agreement with the present study, found no significant correlation between PTH and BMI, while Ahlström et al. [31] and Premaor \& Furnanetto [17] found positive and significant correlations between these variables. The authors attributed these significant results to the ability of adipocytes to store vitamin 
Table 3. Correlation (spearman) between variables related to cardiovascular risk and 25(OH)-vitamin D levels.

\begin{tabular}{ccc}
\hline Variables & r-value & p-value \\
\hline SBP with use of medicine & 0.009 & 0.948 \\
DBP with medicine & -0.057 & 0.673 \\
SBP without use of medicine & -0.152 & 0.337 \\
DBP without medicine & -0.105 & 0.509 \\
Fasting blood glucose & -0.042 & 0.680 \\
Body mass index & -0.144 & 0.154 \\
Waist Circumference & -0.173 & 0.085 \\
Total-Cholesterol & -0.126 & 0.210 \\
LDL-Cholesterol & -0.114 & 0.261 \\
HDL-Cholesterol & -0.017 & 0.863 \\
Triacylglycerol & -0.120 & 0.234 \\
\hline
\end{tabular}

Table 4. Correlation (spearman) between variables related to cardiovascular risk and PTH levels.

\begin{tabular}{ccc}
\hline Variables & r-value & p-value \\
\hline SBP (mmHg) & -0.124 & 0.218 \\
DBP (mmHg) & -0.201 & 0.045 \\
Fasting blood glucose (ml/dL) & -0.078 & 0.443 \\
Body Mass Index (kg/m²) & 0.023 & 0.818 \\
Waist Circumference (cm) & 0.027 & 0.787 \\
Total Cholesterol (ml/dL) & -0.175 & 0.081 \\
LDL-Cholesterol (ml/dL) & -0.145 & 0.149 \\
HDL-Cholesterol (ml/dL) & -0.010 & 0.918 \\
Triacylglycerol (ml/dL) & -0.137 & 0.175 \\
\hline
\end{tabular}

D, which makes this vitamin biologically unavailable [10] [32]-[34]. As such, low levels of vitamin D and consequently high levels of PTH contribute to the elevation of intracellular calcium in adipocytes, stimulating lipogenesis.

Data from 15088 individuals from a study by NHANES III showed an inverse association between obesity and vitamin D [10]. Studies have found a significant association between vitamin D and visceral obesity [34] [35], whilst others have not [8] [36]. Cigolini et al. [8], in a case-control study, did not find differences in body fat, when comparing individuals with or without vitamin D deficiency.

Regarding blood pressure, data from NHANES III (USA) showed an inverse correlation between SBP and vitamin D [12], and other studies have shown similar associations [37] [38]. The role of vitamin D in the reninangiotensin-aldosterone system is the most plausible explanation for the results [13]. However, other authors, similarly to us, failed to find significant correlations between SBP and DBP with vitamin D [35] [36].

In agreement with our study, neither Ahlströn et al. [30] nor Hjelmesaeth et al. [38] found any significant correlation between PTH and blood glucose, or between PTH and LDL-cholesterol. However, Ahlströn et al. [31], as well as Hjelmesaeth et al. [39] found a negative and significant correlation between PTH and HDLcholesterol, and also a positive and significant correlation between PTH and triacylglycerol. 
Ponda et al. [40] showed an inverse correlation between vitamin D and total cholesterol and LDL-cholesterol, and others with triacylglycerol [8] [10] [36] [40] [41]. Some studies have also suggested a positive association between vitamin D and HDL-cholesterol [40] [41], but other studies did not find any significant association with HDL-c, LDL-c and total cholesterol [8] [10] [36]. As vitamin D contributes to vascular endothelial growth factor and cytokine production, understanding the role of this vitamin in CVD risk remains important [13].

Studies have found an inverse correlation between vitamin D and blood glucose, in both genders [42] or only in men [36]. Animal studies showed that low levels of vitamin D lead to low insulin synthesis by pancreatic tissues. It has been postulated that the binding of vitamin D and VDR present in pancreatic islets triggers a genomic pathway related to insulin secretion [43] [44]. Despite those findings in literature, we did not find significant correlation between blood glucose and vitamin D.

It is important to highlight some limitations of the present study. It should be pointed out that there exist a number of potential confounding factors in observational studies on vitamin D, and some of these confounder were present in our study; age, obesity, smoking, sedentary lifestyle, chronic inflammation, medication, genetics, or even assay heterogeneity [7]. In addition, any disease state makes the individual more sedentary, with less exposure to sunlight, signifying reverse causality [10]. Additionally, the investigation of inflammation markers, and also genetic polymorphisms of vitamin D receptor, could allow a better understanding of our results. It's also important to highlight the regional feature of our work. Although it's important to understand Brazilian specificity, our results could not be extrapolated to other locations.

\section{Conclusion}

Under our study conditions, we found low levels of vitamin D, and the prevalence of a number of risk factors for CVD. Associations between vitamin D, PTH and CVD risk did not present significance, probably due to the numerous confounders existing in elderly studies. Vitamin D may constitute an additional risk factor for CVD, but not necessarily an independent factor.

\section{References}

[1] Yusuf, S., Hawken, S., Ôunpuu, S., Dans, T., Avezum, A., Lanas, F., McQueen, M., Budaj, A., Pais, P., Varigos, J. and Lisheng, L. (2004) Effect of Potentially Modifiable Risk Factors Associated with Myocardial Infarction in 52 Countries (the INTERHEART Study): Case-Control Study. Lancet, 364, 937-952. http://dx.doi.org/10.1016/S0140-6736(04)17018-9

[2] Piegas, L.S., Avezum, A., Pereira, J.C., Neto, J.M., Hoepfner, C., Farran, J.A., Ramos, R., Timerman, A. and Esteves, J.P. (2003) Risk Factors for Myocardial Infarction in Brazil. American Heart Journal, 146, 331-338. http://dx.doi.org/10.1016/S0002-8703(03)00181-9

[3] WHO-World Health Organization (2002) Diet, Nutrition and the Prevention of Chronic Diseases: Report of a Joint WHO/FAO Expert Consultation. Series 916, World Health Organization, Geneva.

[4] Holick, M.F. (2007) Vitamin D Deficiency. New England Journal of Medicine, 357, 266-281. http://dx.doi.org/10.1056/NEJMra070553

[5] Judd, S.E. and Tangpricha, V. (2009) Vitamin D Deficiency and Risk for Cardiovascular Disease. American Journal of Medical Science, 338, 40-44. http://dx.doi.org/10.1097/MAJ.0b013e3181aaee91

[6] Zittermann, A. and Gummert, J.F. (2010) Sun, Vitamin D and Cardiovascular Disease. Journal of Photochemistry and Photobiology B, 101, 124-129. http://dx.doi.org/10.1016/j.jphotobiol.2010.01.006

[7] Beveridge, L.A. and Witham, M.D. (2013) Vitamin D and the Cardiovascular System. Osteoporosis International, 24, 2167-2180. http://dx.doi.org/10.1007/s00198-013-2281-1

[8] Cigolini, M., Iagulli, M.P., Miconi, V., Galiotto, M., Lombardi, S. and Targher, G. (2006) Serum 25-Hydroxyvitamin D3 Concentrations and Prevalence of Cardiovascular Disease among Type 2 Diabetic patients. Diabetes Care, 29, $722-$ 724. http://dx.doi.org/10.2337/diacare.29.03.06.dc05-2148

[9] Martini, L.A. and Wood, R.J. (2008) Vitamin D and Blood Pressure Connection: Update on Epidemiologic, Clinical, and Mechanistic Evidence. Nutrition Reviews, 66, 291-297. http://dx.doi.org/10.1111/j.1753-4887.2008.00035.x

[10] Martins, D., Wolf, M., Pan, D., Zadshir, A., Tareen, N., Thadhani, R., Felsenfeld, A., Levine, B., Mehrotra, R. and Norris, K. (2007) Prevalence of Cardiovascular Risk Factors and the Serum Levels of 25-Hydroxyvitamin D in the United States: Data from the Third National Health and Nutrition Examination Survey. Archives of Internal Medicine, 167, 1159-1165. http://dx.doi.org/10.1001/archinte.167.11.1159

[11] Saraiva, G.L., Cendoroglo, M.S., Ramos, L.R., Araújo, L.M., Vieira, J.G., Maeda, S.S., Borba, V.Z., Kunii, I., Havashi, 
L.F. and Lazaretti-Castro, M. (2007) Prevalence of Vitamin D Deficiency, Insufficiency and Secondary Hyperparathyroidism in the Elderly Inpatients and Living in the Community of the City of São Paulo, Brazil. Arq Bras Endocrinol Metabol, 51, 437-442. http://dx.doi.org/10.1590/S0004-27302007000300012

[12] Scragg, R., Sowers, M. and Bell, C. (2004) Third National Health and Nutrition Examination Survey. Serum 25-Hydroxyvitamin D, Diabetes, and Ethnicity in the Third National Health and Nutrition Examination Survey. Diabetes Care, 27, 2813-2818. http://dx.doi.org/10.2337/diacare.27.12.2813

[13] Reddy Vanga, S., Good, M., Howard, P.A. and Vacek, J.L. (2010) Role of Vitamin D in Cardiovascular Health. American Journal of Cardiology, 106, 798-805. http://dx.doi.org/10.1016/j.amjcard.2010.04.042

[14] Wang, T.J., Pencina, M.J., Booth, S.L., Jacques, P.F., Ingelsson, E., Lanier, K., Benjamin, E.J., D’Agostino, R.B., Wolf, M. and Vasan, R.S. (2008) Vitamin D Deficiency and Risk of Cardiovascular Disease. Circulation, 117, 503-511. http://dx.doi.org/10.1161/CIRCULATIONAHA.107.706127

[15] Saleh, F.N., Schirmer, H., Sundsfjord, J. and Jorde R. (2003) Parathyroid Hormone and Left Ventricular Hypertrophy. European Heart Journal, 24, 2054-2060. http://dx.doi.org/10.1016/j.ehj.2003.09.010

[16] Bandeira, F., Griz, L., Dreyer, P., Eufrazino, C., Bandeira, C. and Freese, E. (2006) Vitamin D Deficiency: A Global Perspective. Arquivos Brasileiros de Endocrinologia \& Metabologia, 50, 640-646. http://dx.doi.org/10.1590/S0004-27302006000400009

[17] Premaor, M.O. and Furlanetto, T.W. (2006) Vitamin D Deficiency in Adults: To Better Understand a New Presentation of an Old Disease. Arquivos Brasileiros de Endocrinologia \& Metabologia, 50, 25-37. http://dx.doi.org/10.1590/S0004-27302006000100005

[18] Van der Mei, I.A.F., Ponsonby, A.L., Engelsen, O., Pasco, J.A., McGrath, J.J., Eyles, D.W., Blizzard, L., Dwyer, T., Lucas, R. and Jones, G. (2007) The High Prevalence of Vitamin D Insufficiency across Australian Populations Is Only Partly Explained by Season and Latitude. Environmental Health Perspectives, 115, 1132-1139. http://dx.doi.org/10.1289/ehp.9937

[19] IBGE-Instituto Brasileiro de Geografia e Estatística-Censo (2010) Distribuição da população por sexo, segundo grupos de idade. http://www.censo2010.ibge.gov.br/sinopse/webservice/

[20] Chumlea, W.C., Roche, A.F. and Steinbaugh, M.L. (1985) Estimating Stature from Knee Height for Persons 60 to 90 Years of Age. Journal of the American Geriatrics Society, 33, 116-120.

[21] Gibson, R. (2005) Principles of Nutritional Assessment. 2rd Edition, Oxford University Press, Oxford.

[22] Lebrão, M.L. and Duarte, Y.A.O. (2003) Organização Pan-Americana de Saúde-OPAS/OMS. SABE-Saúde. Bemestar e Envelhecimento-O Projeto SABE no Município de São Paulo: Uma abordagem inicial. Athalaia Bureau, São Paulo.

[23] WHO-World Health Organization (1995) Physical Status: The Use and Interpretation of Anthropometry. Word Health Organization, Geneva, No. 854, 375-409.

[24] SBC-Sociedade Brasileira de Cardiologia (2010) VI Diretrizes Brasileiras de Hipertensão. Arquivos Brasileiros de Cardiologia, 95, 1-51.

[25] BRASIL. Ministério da Saúde. Secretaria de Atenção a Saúde. Departamento de Atenção Básica (2006) Envelhecimento e Saúde da Pessoa Idosa. Ministério da Saúde, Brasília.

[26] Holick, M.F., Binkley, N.C., Bischoff-Ferrari, H.A., Gordon, C.M., Hanley, D.A., Heaney, R.P. and Weaver, C.M. (2011) Evaluation, Treatment, and Prevention of Vitamin D Deficiency: An Endocrine Society Clinical Practice Guideline. Journal of Clinical Endocrinology \& Metabolism, 96, 1911-1930. http://dx.doi.org/ 10.1210/jc.2011-0385

[27] Friedewald, W.T., Levy, R.I. and Fredrickson, D.S. (1972) Estimation of the Concentration of Low-Density Lipoprotein Cholesterol in Plasma, without Use of the Preparative Ultracentrifuge. Clinical Chemistry, 18, 499-502.

[28] Sposito, A.C., Caramelli, B., Fonseca, F.A.H. and Bertolami, M.C. (2007) IV Brazilian Guideline for Dyslipidemia and Atherosclerosis Prevention: Department of Atherosclerosis of Brazilian Society of Cardiology. Arquivos Brasileiros de Cardiologia, 88, 2-19. http://dx.doi.org/10.1590/S0066-782X2007000700002

[29] SBD-Sociedade Brasileira de Diabetes (2009) Diretrizes da Sociedade Brasileira de Diabetes. 3rd Edition, Sociedade Brasileira de Diabetes, Itapevi, São Paulo.

[30] Kimmons, J.E., Blanck, H.M., Tohill, B.C., Zhang, J. and Khan, L.K. (2006) Associations between Body Mass Index and the Prevalence of Low Micronutrient Levels among US Adults. Medscape General Medicine, 8, 59.

[31] Ahlström, T., Hagström, E., Larsson, A., Rudberg, C., Lind, L. and Hellman, P. (2009) Correlation between Plasma Calcium, Parathyroid Hormone (PTH) and the Metabolic Syndrome (MetS) in a Community-Based Cohort of Men and Women. Clinical Endocrinology, 71, 673-678. http://dx.doi.org/10.1111/j.1365-2265.2009.03558.x

[32] Adams, J.S. and Hewison, M. (2010) Update in Vitamin D. Journal of Clinical Endocrinology \& Metabolism, 95, 471478. http://dx.doi.org/10.1210/jc.2009-1773 
[33] Takiishi, T., Gysemans, C., Bouillon, R. and Mathieu, C. (2010) Vitamin D and Diabetes. Endocrinology and Metabolism Clinics of North America, 39, 419-446. http://dx.doi.org/10.1016/j.rdc.2012.03.015

[34] Young, K.A., Engelman, C.D., Langefeld, C.D., Hairston, K.G., Haffner, S.M., Bryer-Ash, M. and Norris, J.M. (2009) Association of Plasma Vitamin D Levels with Adiposity in Hispanic and African Americans. Journal of Clinical Endocrinology \& Metabolism, 94, 3306-3313. http://dx.doi.org/10.1210/jc.2009-0079

[35] Snijder, M.B., Lips, P., Seidell, J.C., Visser, M., Deeg, D.J., Dekker, J.M. and Van Dam, R.M. (2007) Vitamin D Status and Parathyroid Hormone Levels in Relation to Blood Pressure: A Population-Based Study in Older Men and Women. Journal of Internal Medicine, 261, 558-565. http://dx.doi.org/10.1111/j.1365-2796.2007.01778.x

[36] Reis, J.P., Von Mühlen, D., Kritz-Silverstein, D., Wingard, D.L. and Barrett-Connor, E. (2007) Vitamin D, Parathyroid Hormone Levels, and the Prevalence of Metabolic Syndrome in Community-Dwelling Older Adults. Diabetes Care, 30 , 1549-1555. http://dx.doi.org/10.2337/dc06-2438

[37] Almirall, J., Vaqueiro, M., Baré, M.L. and Anton, E. (2010) Association of Low Serum 25-Hydroxyvitamin D Levels and High Arterial Blood Pressure in the Elderly. Nephrology Dialysis Transplantation, 25, 503-509. http://dx.doi.org/10.1093/ndt/gfp470

[38] Pfeifer, M., Begerow, B., Minne, H.W., Nachtigall, D. and Hansen, C. (2001) Effects of a Short-Term Vitamin D(3) and Calcium Supplementation on Blood Pressure and Parathyroid Hormone Levels in Elderly Women. Journal of Clinical Endocrinology and Metabolism, 86, 1633-1637.

[39] Hjelmesaeth, J., Hofsø, D., Aasheim, E.T., Jenssen, T., Moan, J., Hager, H., Røislien, J. and Bollerslev, V. (2009) Parathyroid Hormone, but Not Vitamin D, Is Associated with the Metabolic Syndrome in Morbidly Obese Women and Men: A Cross-Sectional Study. Cardiovascular Diabetology, 8, 7. http://dx.doi.org/10.1186/1475-2840-8-7

[40] Ponda, M.P., Huang, X., Odeh, M.A., Breslow, J.L. and Kaufman, H.W. (2007) Vitamin D May Not Improve Lipid Levels: A Serial Clinical Laboratory Data Study. Circulation, 17, 270-277. http://dx.doi.org/10.1161/CIRCULATIONAHA.111.077875

[41] Liu, E., Meigs, J.B., Pittas, A.G., Mckeown, N.M., Economos, C.D., Booth, S.L. and Jacques, P.F. (2009) Plasma 25-Hydroxyvitamin D Is Associated with Markers of the Insulin Resistant Phenotype in Nondiabetic Adults. Journal of Nutrition, 139, 329-334. http://dx.doi.org/10.3945/jn.108.093831

[42] Mattila, C., Knekt, P., Männistö, S., Rissanen, H., Laaksonen, M.A., Montonen, J. and Reunanen, A. (2007) Serum 25-Hydroxyvitamin D Concentration and Subsequent Risk of Type 2 Diabetes. Diabetes Care, 30, 2569-2570. http://dx.doi.org/10.2337/dc07-0292

[43] Norman, A.W., Frankel, J.B., Heldt, A.M. and Grodsky, G.M. (1980) Vitamin D Deficiency Inhibits Pancreatic Secretion of Insulin. Science, 209, 823-825. http://dx.doi.org/10.1126/science.6250216

[44] Mathieu, C., Waer, M., Laureys, J., Rutgeerts, O. and Bouillon, R. (1994) Prevention of Autoimmune Diabetes in NOD Mice by 1, 25 Dihydroxyvitamin D3. Diabetologia, 37, 552-558. 